\title{
Evaluation of Cardiovascular Risk Factors in Women with Uterine Leimyoma: Is There a Link with Atherosclerosis?
}

\author{
Nasir Sivri', Tülin Yalta², Cenk Sayın ${ }^{3}$, Kenan Yalta' ${ }^{1}$ Fulya Özpuyan², Ebru Taştekin², Ertan Yetkin ${ }^{4}$ \\ ${ }^{1}$ Department of Cardiology, Faculty of Medicine, Trakya Univeristy, Edirne, Turkey \\ ${ }^{2}$ Department of Pathology, Faculty of Medicine, Trakya Univeristy, Edirne, Turkey \\ ${ }^{3}$ Department of Gynecology and Obstetrics, Faculty of Medicine, Trakya Univeristy, Edirne, Turkey \\ ${ }^{4}$ Department of Cardiology, IMC Hospital, Mersin Turkey
}

\begin{abstract}
Objective: Both uterine leimyoma (UL) and cardiovascular disease are public health problems affecting women at different age ranges. Smoking, obesity, and hypertension have been shown to be associated with UL in different random studies. However cardiovascular risk factors have not been evaluated systematically in patients with UL. Accordingly, we aimed to evaluate the cardiovascular risk factors and their relation with the presence of UL.

Material and Methods: One hundred and eighty nine patients with the pathological diagnosis of UL and one hundred and eighty nine age matched control subjects without UL were retrospectively included in the study from our data base of the pathology and gynecology departments. Controls were patients with intact uteri who had visited the same physicians for a routine checkup that included a pelvic examination and uterine sonogram and without mention of physical findings consistent with UL. The following clinical and demographic parameters were recorded; age, sex, hypertension, diabetes mellitus, and hypercholesterolemia. Current cigarette smoking was defined as active smoking within the past 12 months.
\end{abstract}

Results: Comparison of cardiovascular risk factors between with and without UL revealed that the presence of hypertension (80 (42.3\%) vs 53 (28\%) $\mathrm{p}=0.004)$ diabetes mellitus $(33(17.4 \%)$ vs. $16(8.4 \%) \mathrm{p}=0.009)$, smoking $(31(16.4 \%)$ vs. $11(5.8 \%) \mathrm{p}=0.001)$, were significantly higher in patients with UL than in control subjects. The mean-age and presence of hyperlipidemia were comparable between the two groups. Logistic regression analysis revealed an independent and positive association of UL with the presence of hypertension (odds ratio $2.02 \mathrm{Cl}: 1.25-3.27 \mathrm{p}=0.004$ ), diabetes mellitus (odds ratio 2.43 Cl: 1.23-4.79 $\mathrm{p}=0.010$ ), and smoking status (odds ratio $3.46 \mathrm{Cl}: 1.65-7.22 \mathrm{p}=0.001$ ).

Conclusion: We have shown that major cardiovascular risk factors namely, hypertension, diabetes mellitus and smoking are significantly and independently associated with UL. Our findings highlight the possible association of UL with atherosclerosis.

Key Words: Atherosclerosis, cardiovascular risk factors, hypertension, diabetes mellitus, smoking, uterine leimyomata (UL)

Received: 06.09.2011 Accepted: 11.02.2012

\section{Introduction}

Uterine leiomyomata (UL) (also known as fibroids or myomas) are the most common pelvic neoplasms in women (1-3). Epidemiologic studies demonstrate that these hormone dependent, benign tumors follow a woman's reproductive life cycle, increasing in risk with age up until the fifth decade, followed by a precipitous decline at menopause $(4,5)$. Although these benign tumors represent a significant public health concern, the epidemiology of uterine leiomyomata is poorly understood. The true population prevalence of fibroids, however, is probably underestimated because of the unknown distribution of subclinical tumors (3). Studies screening randomly selected women using ultrasonography or pathologic examination of uteri have reported uterine leiomyomata prevalence values ranging from 5.4 to 77 percent (6-9).

Although the risk of UL decreases at menopause, the risk of coronary artery disease increases after menopause. Both the UL and cardiovascular disease are public health problems affecting women at different age ranges. Smoking, obesity, and hypertension have been shown to be associated with UL in different random studies $(1,10,11)$. However, cardiovascular risk factors have not been evaluated systematically in patients with UL. Accordingly, we aimed to evaluate the cardiovascular risk factors and their relation with the presence of UL.

\section{Material and Methods}

One hundred and eighty nine patients with a pathological diagnosis of UL and one hundred and eighty nine age matched control subjects without UL were retrospectively included in the study from our data base of the pathology and gynecology department. Controls were patients with intact uteri who had visited the same department for a routine check-up or complaints of pelvic pain, dysuria, poly-or dys-menorrhea, anemia, and infertility that included a pelvic examination, and uterine sonogram. Control subjects had no UL proven by uterine sonography. The following clinical and demographic parameters were recorded; age, sex, hypertension (known hypertension 
treated with antihypertensive drugs, two or more blood pressure recordings greater than $140 / 90 \mathrm{~mm} \mathrm{Hg}$ ), diabetes mellitus (known diabetes treated with diet or drugs or both; or either a fasting serum glucose of more than $126 \mathrm{mg} / \mathrm{dL}$ ), hypercholesterolemia (known treated hypercholesterolemia or fasting or non-fasting serum cholesterol concentrations higher than 200 $\mathrm{mg} / \mathrm{dL}$ ). Current cigarette smoking was defined as active smoking within the past 12 months.

Patients with hepatic or renal failure, polycystic ovarian syndrome, malignancies and other systemic disease were not included in the study.

\section{Statistical Analysis}

Results are expressed as the mean $\pm S D$ and percents. The differences between the two groups were tested for significance by chi-square and independent samples t-tests where suitable. Differences were considered significant at $p<0.05$. We investigated the association of different variables on UL using logistic regression analysis. Parameters, namely, age gender, presence of hypertension, hyperlipidemia, diabetes mellitus, smoking status, and family history of coronary artery disease were included in the analysis. Statistical analyses were performed by using SPSS 15.0 Statistical Package Program for Windows (SPSS Inc., Chicago, Illinois, USA).

\section{Results}

Patients and control subjects' baseline characteristics are presented in Table 1. Comparison of cardiovascular risk factors between two groups revealed that presence of hypertension $(80(42.3 \%)$ vs. $53(28 \%) \mathrm{p}=0.004)$ diabetes mellitus (33 (17.4\%) vs. $16(8.4 \%) p=0.009)$, smoking (31 (16.4\%) vs. $11(5.8 \%) p=0.001)$. Age and presence of hyperlipidemia were comparable between the two groups (Table 1). Logistic regression analysis revealed an independent and positive association of UL with the presence of hypertension (odds ratio 2.02 Cl: 1.25-3.27 $p=0.004$ ), diabetes mellitus (odds ratio 2.43 $\mathrm{Cl}$ : 1.23-4.79 $\mathrm{p}=0.010$ ), and smoking status (odds ratio 3.46 $\mathrm{Cl}$ : 1.65-7.22 $\mathrm{p}=0.001$, Table 2).

\section{Discussion}

Leiomyomas are the most common female reproductive tract tumors. They are probably of unicellular origin (12). Although studies have not clarified the exact process, uterine fibroid tumors arise during the reproductive years and tend to enlarge during pregnancy and regress after menopause. The documented risk factors for uterine fibroids are, black race, family history of uterine fibroids, age $>40$ years, nulliparity, obesity, and hypertension $(1,13,17)$.

The main finding of our study is that cardiovascular risk factors namely, hypertension, diabetes mellitus, and smoking have been found to be independently and positively associated with uterine fibroids. Since age was matched for control subjects, only hyperlipidemia among the cardiovascular risk factors is independent of uterine fibroids.

Coexistence of hypertension with UL has been documented in several small studies $(10,16-20)$. Boynton-Jarrett et al.(11) has reported the first prospective data demonstrating a dose response relation between diastolic blood pressure and fibroid incidence, with higher blood pressure associated with higher fibroid risk. The association of UL with hypertension has been explained partially by the reverse-causality interpretation suggesting that UL may cause hypertension as a consequence of urinary tract obstruction by large tumors $(10,20)$. Another explanation has been made by the reninangiotensin system, which is implicated in the pathogenesis of hypertension (21-23). Angiotensin II (AT-II) has a proliferative action in that it stimulates the hypertrophy of cardiac and vascular smooth muscle $(21,23)$. AT-II receptor expression has also been shown in various tissues, including the uterine myometrium and vascular smooth muscle cells (24). Local expression of these factors, such as transforming growth factor $\beta$ and platelet derived growth factor, are postulated to be critical to the growth of leiomyomata as well $(25,26)$. In accordance with previously published literature, hypertension has been found to be independently associated with UL with a relatively high odds ratio of 2.02 ( $\mathrm{Cl}: 1.25-3.27)$.

In addition to hypertension, we have also found that the presence of diabetes mellitus is an independent factor for UL with an odds ratio of $2.43(\mathrm{Cl}: 1.23-4.79)$. Although it did not have statistical significance, a pattern similar to the association of UL with hypertension was observed by Faerstein et al. (18). Higher proportions of cases had more severe diabetes, were younger at diabetes diagnosis, and had diabetes of longer duration. To the best of our knowledge, this is the first report documenting an independent association between diabetes mellitus and UL. Indeed, it is reasonable to expect such an effect of diabetes mellitus on UL formation. Effects of diabetes mellitus on progression of atherosclerosis have been shown by the demonstration of increased carotid artery intima-media thickness $(27,28)$. Diabetes mellitus is known to

Table 1. Comparison of patient with myoma uteri and control subjects

\begin{tabular}{|lccc|}
\hline Variables & $\begin{array}{c}\text { Myoma } \\
\text { Uteri } \\
(\mathbf{n = 1 8 9 )}\end{array}$ & $\begin{array}{c}\text { Control } \\
\text { Subjects } \\
(\mathbf{n = 1 8 9 )}\end{array}$ & p value \\
\hline Age (Years) & $45 \pm 9$ & $45 \pm 8$ & 0.94 \\
Hypertension & $80(42 \%)$ & $53(28 \%)$ & 0.04 \\
Diabetes Mellitus & $33(17 \%)$ & $16(8 \%)$ & 0.09 \\
Hyperlipidemia & $31(16 \%)$ & $22(11 \%)$ & 0.18 \\
Smoking & $31(16 \%)$ & $11(5 \%)$ & 0.01 \\
\hline
\end{tabular}

Table 2. Logistic regression analysis

\begin{tabular}{|lccc|}
\hline Variables & $\begin{array}{c}\text { Odds } \\
\text { ratio }\end{array}$ & $\begin{array}{c}\text { Confidence } \\
\text { interval }\end{array}$ & $p$ value \\
\hline Age & 0.98 & $0.95-1.00$ & 0.184 \\
Hypertension & 2.02 & $1.25-3.27$ & 0.004 \\
Diabetes Mellitus & 2.43 & $1.23-4.79$ & 0.010 \\
Hyperlipidemia & 1.51 & $0.82-2.79$ & 0.186 \\
Smoking & 3.46 & $1.65-7.22$ & 0.001 \\
\hline
\end{tabular}


promote negative remodeling in the arterial wall and impair compensatory arterial enlargement during the course of the atherosclerotic process $(29,30)$. Hyperinsulinemia is a good candidate for UL formation by means of myometrial smooth muscle cell proliferation and/or increasing circulating levels of ovarian hormones. Insulin resistance and hyperinsulinemia have been proposed as possible mechanisms underlying pathophysiologic pathways connecting obesity, diabetes, hypertension, and hyperlipidemia, eventually leading to atherosclerosis (31). Additionally, insulin has been shown to promote cell mitosis, to promote vascular smooth muscle proliferation, and in particular, to stimulate the growth of UL cells in tissue culture (32-34). Insulin may have also a specific gonadotropic function, stimulating ovarian secretion via insulin receptors or receptors for insulin-like growth factors (35).

On the contrary, in previous literatures in which smoking has been reported as a negative risk factor, we have found that smoking is positively and independently associated with UL formation. Smoking has been reported to reduce the risk of UL in several studies $(1,8,36,37)$. No statistically significant associations have been observed between cigarette smoking variables and UL risk. On the other hand, smoking for more than 19 years is associated with a 40 percent decreased risk of UL (18). Although smoking is considered to be associated with an estrogen-deficient state which is supposed to be an underlying reason for less frequent UL in smokers in published literature, smoking is one of the major risk factor for atherosclerosis (38). A common key element of atherosclerosis and UL is smooth muscle cell proliferation. Recent epidemiological studies have shown that smoking is a significant and independent risk factor for cardiovascular disease, and peripheral vascular disease $(39,40)$. Nicotine, a major constituent of tobacco, is known to be directly involved in smooth muscle cell proliferation (41). UL has a monoclonal origin, which has also been postulated for the atheromatous plaque; cells from both conditions behave identically in culture (42-44). In terms of smooth muscle cell proliferation, it is reasonable to expect a positive association with smoking and UL.

\section{Conclusion}

We have shown that major cardiovascular risk factors, namely, hypertension, diabetes mellitus and smoking are significantly and independently associated with UL. Our findings highlight the possible association of UL with atherosclerosis. Therefore, further studies are needed to elucidate the role of cardiovascular risk factors or atherosclerosis in the pathogenesis of UL or vice versa.

\section{Conflict of Interest}

No conflict of interest was declared by the authors.

\section{References}

1. Ross RK, Pike MC, Vessey MP, Bull D, Yeates D, Casagrande JT. Risk factors for uterine fibroids: reduced risk associated with oral contraceptives. Br Med J 1986;293:359-62. [CrossRef]
2. Vollenhoven B. Introduction: the epidemiology of uterine leiomyomas. Baillieres Clin Obstet Gynaecol 1998;12:169-76. [CrossRef]

3. Newbold RR, DiAugustine RP, Risinger JI, Everitt JI, Walmer DK, Parrott EC, et al. Advances in uterine leiomyoma research: conference overview, summary, and future research recommendations. Environ Health Perspect 2000;108:769-73. [CrossRef]

4. Cramer SF, Horiszny JA, Leppert P. Epidemiology of uterine leiomyomas. With an etiologic hypothesis. J Reprod Med 1995;40:595-600.

5. Schwartz SM, Marshall LM, Baird DD. Epidemiologic contributions to understanding the etiology of uterine leiomyomata. Environ Health Perspect 2000;108:821-7. [CrossRef]

6. Day Baird D, Dunson DB, Hill MC, Cousins D, Schectman JM. High cumulative incidence of uterine leiomyoma in black and white women: ultrasound evidence. Am J Obstet Gynecol 2003;188:100-7. [CrossRef]

7. Borgfeldt C, Andolf E. Transvaginal ultrasonographic findings in the uterus and the endometrium: low prevalence of leiomyoma in a random sample of women age $25-40$ years. Acta Obstet Gynecol Scand 2000;79:202-7. [CrossRef]

8. Luoto R, Kaprio J, Rutanen EM, Taipale P, Perola M, Koskenvuo M. Heritability and risk factors of uterine fibroids-the Finnish Twin Cohort Study. Maturitas 2000;37:15-26. [CrossRef]

9. Cramer SF, Patel A. The frequency of uterine leiomyomas. Am J Clin Pathol 990;94:435-8.

10. Marshall LM, Spiegelman D, Manson JE, Goldman MB, Barbieri $\mathrm{RL}$, Stampfer MJ, et al. Risk of uterine leiomyomata among premenopausal women in relation to body size and cigarette smoking. Epidemiology 1998;9:511-7. [CrossRef]

11. Boynton-Jarrett R, Rich-Edwards J, Malspeis S, A. Missmer S, Wright R. A prospective study of hypertension and risk of uterine leiomyomata. Am J Epidemiol 2005;161:628-38. [CrossRef]

12. Hashimoto K, Azuma C, Kamiura S, Kimura T, Nobunaga T, Kanai $\mathrm{T}$, et al. Clonal determination of uterine leiomyomas by analyzing differential inactivation of the X-chromosome-linked phosphoglycerokinase gene. Gynecol Obstet Invest 1995;40:204-8. [CrossRef]

13. Wise LA, Palmer JR, Stewart EA, Rosenberg L. Age-specific incidence rates for self-reported uterine leiomyomata in the Black Women's Health Study. Obstet Gynaecol 2005;105:563-8. [CrossRef]

14. Kjerulff KH, Langenberg P, Seidman JD, Stolley PD, Guzinski GM. Uterine leiomyomas. Racial differences in severity, symptoms and age of diagnosis. J Reprod Med 1996;41:483-90.

15. Ligon $\mathrm{AH}$, Morton $\mathrm{CC}$. Leiomyomata: heritability and cytogenetic studies. Hum Reprod Update 2001;7:8-14. [CrossRef]

16. Chiaffarino F, Parazzini F, La Vecchia C, Marsico S, Surace M, Ricci E. Use of oral contraceptives and uterine fibroids: results from a casecontrol study. Br J Obstet Gynaecol 1999;106:857-60. [CrossRef]

17. Lumbiganon $P$, Rugpao S, Phandhu-fung $S$, Laopaiboon M, Vudhikamraksa N, Werawatakul Y. Protective effect of depotedroxyprogesterone acetate on surgically treated uterine leiomyomas: a multicentre casecontrol study. Br J Obstet Gynaecol 1996;103:909-14. [CrossRef]

18. Faerstein E, Szklo M, Rosenshein N. Risk factors for uterine leiomyoma: a practice-based case-control study I. African American heritage, reproductive history, body size, and smoking. Am J Epidemiol 2001;153:1-10. [CrossRef]

19. Okoronkwo MO. Body weight and uterine leiomyomas among women in Nigeria. West Afr J Med 1999;18:52-4.

20. Sato F, Nishi M, Kudo R, Miyake H. Body fat distribution and uterine leiomyomas. J Epidemiol 1998;8:176-80. [CrossRef]

21. Silver MA., Raghuvir R, Fedirko B, Esler D. Systemic hypertension among women with uterine leiomyomata: potential final common pathways of target end-organ remodeling. J Clin Hypertens (Greenwich) 2005;7:664-8. [CrossRef]

22. Kawano H, Do YS, Kawano Y, Starnes V, Barr M, Law RE, et al. Angiotensin II has multiple profibrotic effects in human cardiac fibroblast. Circulation 2000;101:1130-7. [CrossRef]

23. Itoh H, Mukoyama M, Pratt RE, Gibbons GH, Dzau VJ. Multiple 
autocrine growth factors modulate vascular smooth muscle cell growth response to angiotensin II. J Clin Invest 1993;91:2268-74. [CrossRef]

24. Baker KM, Booz GW, Dostal DE. Cardiac actions of angiotensin II: role of intracardiac renin angiotensin system. Annu Rev Physiol 1992;54:227-41. [CrossRef]

25. Brandon DD, Bethea CL, Strawn EY, Novy MJ, Burry KA, Harrington $\mathrm{MS}$, et al. Progesterone receptor messenger ribonucleic acid and protein are overexpressed in human uterine leiomyomas. Am J Obstet Gynecol 1993;169:78-85.

26. Dou Q, Zhao Y, Tarnuzzer RW, Rong H, Williams RS, Schultz GS, et al. Suppression of transforming growth factor-beta (TGF beta) and TGF beta receptor messenger ribonucleic acid and protein expression in leiomyomata in women receiving gonadotropinreleasing hormone agonist therapy. J Clin Endocrinol Metab 1996;81:3222-30. [CrossRef]

27. Wagenknecht LE, Zaccaro D, Espeland MA, Karter AJ, O'Leary $\mathrm{DH}$, Haffner SM. Diabetes and progression of carotid atherosclerosis: the insulin resistance atherosclerosis study. Arterioscler Thromb Vasc Biol 2003;23:1035-41. [CrossRef]

28. Rajaram V, Pandhya $S$, Patel $S$, Meyer PM, Goldin M, Feinstein MJ, Neems R, Liebson PR, Fiedler BM, Macioch JE, Feinstein SB. Role of surrogate markers in assessing patients with diabetes mellitus and the metabolic syndrome and in evaluating lipid-lowering therapy. Am J Cardiol 2004;93(11A):32C-48C. [CrossRef]

29. Kornowski R, Mintz GS, Lansky J, Hong MK, Kent KM, Pichard AD, et al. Paradoxic decreases in atherosclerotic plaque mass in insulintreated diabetic patients. Am J Cardiol 1998;81:1298-304. [CrossRef]

30. Vavuranakis M, Stefanadis C, Toutouzas K, Pitsavos C, Spanos $V$, Toutouzas P. Impaired compensatory coronary artery enlargement in atherosclerosis contributes to the development of coronary artery stenosis in diabetic patients. An in vivo intravascular ultrasound study. Eur Heart J 1997;18:1090-4. [CrossRef]

31. Reaven GM. Banting lecture 1988. Role of insulin resistance in human disease. Diabetes 1988;37:1595-607. [CrossRef]

32. Yam D. Insulin-cancer relationships: possible dietary implication. Med Hypotheses 1992;38:111-7. [CrossRef]

33. Bornfeldt KE, Arnqvist HJ, Capron L. In vivo proliferation of rat vascular smooth muscle in relation to diabetes mellitus, insulinlike growth factor I and insulin. Diabetologia 1992;35:104-8. [CrossRef]

34. Cramer SF, Robertson AL Jr, Ziats NP, Pearson OH. Growth potential of human uterine leiomyomas: some in vitro observations and their implications. Obstet Gynecol 1985;66:36-41.

35. Poretsky L, Galin MF. The gonadotropic function of insulin. Endocr Rev 1987;8:132-41. [CrossRef]

36. Samadi AR, Lee NC, Flanders WD, Boring JR 3rd, Parris EB. Risk factors for selfreported uterine fibroids: a case-control study. Am J Public Health 1996;86:858-62. [CrossRef]

37. Parazzini F, Negri E, La Vecchia C, Rabaiotti M, Luchini L, Villa A, et al. Uterine myomas and smoking. Results from an Italian study. J Reprod Med 1996;41:316-20.

38. Baron JA, La Vecchia C, Levi F. The antiestrogenic effect of cigarette smoking in women. Am J Obstet Gynecol 1990;162:502-14.

39. Turner RC, Millns H, Neil HA, Stratton IM, Manley SE, Matthews $D R$, et al. Risk factors for coronary artery disease in non-insulin dependent diabetes mellitus: United Kingdom Prospective Diabetes Study (UKPDS:23). BMJ 1998;316:823-8. [CrossRef]

40. Adler Al, Stevens RJ, Neil A, Stratton IM, Boulton AJ, Holman RR. UKPDS 59: Hyperglycemia and other potentially modifiable risk factors for peripheral vascular disease in type 2 diabetes. Diabetes Care 2002;25:894-99. [CrossRef]

41. Li JM, Cui TX, Shiuchi T, Liu HW, Min LJ, Okumura M, et al. Nicotine enhances angiotensin II-induced mitogenic response in vascular smooth muscle cells and fibroblasts. Arterioscler Thromb Vasc Biol 2004;24:80-4. [CrossRef]

42. Mashal RD, Fejzo ML, Friedman AJ, Mitchner N, Nowak RA, Rein MS, et al. Analysis of androgen receptor DNA reveals the independent clonal origins of uterine leiomyomata and the secondary nature of cytogenetic aberrations in the development of leiomyomata. Genes Chromosomes Cancer 1994;11:1-6. [CrossRef]

43. Chung IM, Schwartz SM, Murry CE. Clonal architecture of normal and atherosclerotic aorta: implications for atherogenesis and vascular development. Am J Pathol 1998;152:913-23.

44. Moss NS, Benditt EP. Human atherosclerotic plaque cells and leiomyoma cells. Comparison of in vitro growth characteristics. Am J Pathol 1975;78:175-90. 